Richland, Washington 99352 


\section{DISCLAIMER}

This report was prepared as an account of work sponsored by an agency of the United States Government. Neither the United States Government nor any agency Thereof, nor any of their employees, makes any warranty, express or implied, or assumes any legal liability or responsibility for the accuracy, completeness, or usefulness of any information, apparatus, product, or process disclosed, or represents that its use would not infringe privately owned rights. Reference herein to any specific commercial product, process, or service by trade name, trademark, manufacturer, or otherwise does not necessarily constitute or imply its endorsement, recommendation, or favoring by the United States Government or any agency thereof. The views and opinions of authors expressed herein do not necessarily state or reflect those of the United States Government or any agency thereof. 


\section{DISCLAIMER}

Portions of this document may be illegible in electronic image products. Images are produced from the best available original document. 


\section{LEGAL NOTICE}

This report was prepared as an account of work sponsored by the United States Government. Neither the United States nor the United States Atomic Energy Commission, nor any of their employees, nor any of their contractors, subcontractors, or their employees, makes any warranty, express or implied, or assumes any legal liability or responsibility for the accuracy, completeness or usefulness of any information, apparatus, product or process disclosed, or represents that its use would not infringe privately owned rights.

\section{HANFORD ENGINEERING DEVELOPMENT LABORATORY}

Richland, Washington

operated by

\section{WADCO CORPORATION}

A Subsidiary of Westinghouse Electric Corporation for the

United States Atomic Energy Commission Under Contract No. AT(45-1)-2170 
WHAN - FR - 19

\section{UC-40, Radiation \\ Effects on Materials \\ Conf-700630- -}

UNIAXIAL AND BIAXIAL CREEP-RUPTURE

OF TYPE 316 STAINLESS STEEL

AFTER FAST REACTOR IRRADIATION (a)

A. J. Love 11

R. W. Barker

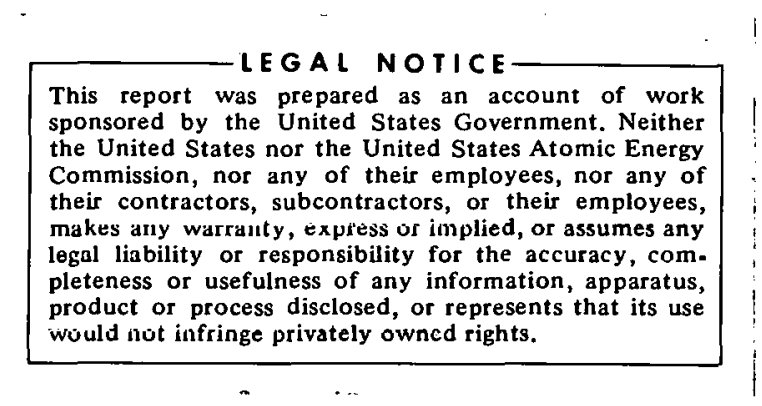

September 1970

FPRST UNRESTRICTED

DistriBution MADE OCT 270

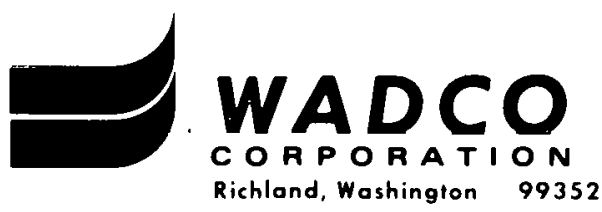

(a) Work performed by Battelle Northwest under Contract No. AT (45-1)-1830. Presented as BNWL-SA-3295 at the ASTM Symposium on Effects of Radiation on Structural Materials, June 29-July 2, 1970, at Niagara Falls, Canada

UNCLASSIF IED 
WHAN - FR - 19

Printed in the United States of America Available from

Clearinghouse for Federal Scientific and Technical Information National Bureau of Standards, U.S. Department of Commerce Springfield, Virginia 22151

Price: Printed Copy $\$ 3.00$; Microfiche $\$ 0.65$ 


\title{
UNIAXIAL AND BIAXIAL CREEP-RUPTURE OF TYPE 316 STAINLESS STEEL AFTER FAST REACTOR IRRADIATION
}

\author{
A. J. Lovell and R.W. Barker
}

\section{$\underline{\text { ABSTRACT }}$}

The degradation in creep-rupture properties of Type 316 stainless steel after fast reactor irradiation has been determined for both uniaxial and biaxial loading conditions. Uniaxial specimens (rod-type) and biaxial specimens (tube-type) were irradiated in the $7 C 4$ position of the EBR-II to a total fluence of $1.2 \times 1022 \mathrm{n} / \mathrm{cm}^{2}\left[1 \times 10^{2} \mathrm{n} / \mathrm{cm}^{2}\right.$ $(E>0.1 \mathrm{MeV})]$ at $\sim 480^{\circ} \mathrm{C}$. Postirradiation tests were performed over the temperature range 538 to $760{ }^{\circ} \mathrm{C}$.

The results from both uniaxial and biaxial tests at $538{ }^{\circ} \mathrm{C}$ show significant losses in rupture iife relative to unirradiated specimens when compared on the basis of initial true stress. Rupture life was reduced by factors down to $1 / 20$ for uniaxial and by factors down to $1 / 40$ for biaxial tests. The substantial loss in rupture life at $538{ }^{\circ} \mathrm{C}$ was primarily a result of high creep rates, and the contribution from ductility loss was relatively smal2. Uniaxial test results at $593{ }^{\circ} \mathrm{C}$ show reductions in rupture life of a factor of $1 / 5$ at $h i g h$ stresses and only small reductions at low stresses. The rupture life for both uniaxial and biaxial tests at $649{ }^{\circ} \mathrm{C}$ show only a factor of $1 / 2$ decrease after irradiation. The decrease becomes more substantial again at $760{ }^{\circ} \mathrm{C}$ with a factor of $1 / 10$ to $1 / 7$ reduction in life. The rupture life reductions at 593, 649 ; and $760{ }^{\circ} \mathrm{C}$ were the results of reduced ductility, with no significant contributions from creep rate differences. The underlying cause of the low ductility at these higher temperatures is assooiated wi.th hel.i.um embritt. lement and defect structure.

Key Words: Creep, stress-rupture, irradiation, structural materials, fast reactor, creep rate, austenitic stainless steel, AISI Type 316, rupture life, ductility. 


\section{THIS PAGE}

\section{WAS INTENTIONALLY \\ LEFT BLANK}




\section{TABLE OF CONTENTS}

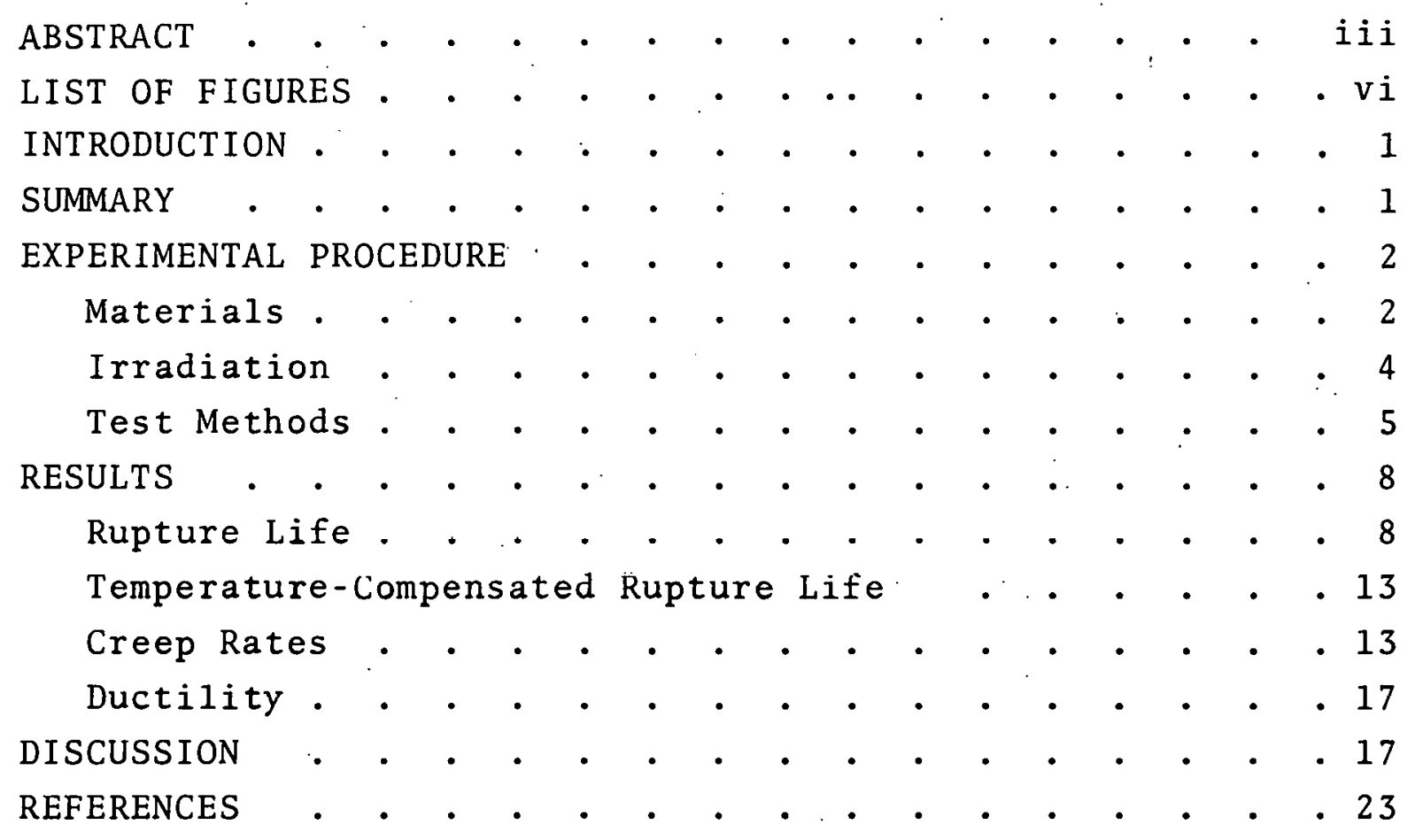




\section{LIST OF FIGURES}

1 Hoop Stress-Strain Curve for $5.3 \mathrm{~mm}$ Diameter $\times 0.2 \mathrm{~mm}$ Wal1 Type 316 SS Subjected to Internal Pressure

2 Effect of EBR-II Irradiation on the Rupture Life of Type 316 SS Determined in Uniaxial Tests

3. Effect of EBR-II Irradiation on the Rupture Life of Type 316 SS Determined in Biaxial Tests

4 Effect of EBR-I.I Irradiation on the Theta Correlation of Uniaxial Test Results on Type 316 SS

5 Effect of EBR-II Irradiation on the Theta Correlation of Biaxial Test Results on Type 316 SS

6 Effect of EBR-II Irradiation on the Minimum Rate of Type 316 SS determined in Uniaxial Tests

7. Effect of EBR-II Irradiation on Average Creep Rate of Type 316 SS Tube Determined in Biaxial Tests 


\section{UNIAXIAL AND BIAXIAL CREEP-RUPTURE}

OF TYPE 316 STAINLESS STEEL

AFTER FAST REACTOR IRRADIATION

A. J. Lovell and R. W. Barker

\section{INTRODUCTION}

The selection of AISI 316 stainless steel (SS) as a prime alloy for application in liquid metal fast breeder reactor systems has prompted a need to know how this alloy is affected by fast neutron irradiation at elevated temperatures. Only limited data on the postirradiation mechanical properties obtained from fast reactor experiments are available for this alloy. This limitation is particularly acute for the time dependent creep and creep-rupture properties. To obtain such information, creep tests have been made on Type 316 SS after fast reactor irradiation in the Experimental Breeder Reactor-II (EBR-II). These tests were designed to determine empirically the stress dependence of minimum creep rate and rupture life and the ductility of this irradiated alloy over the temperature range 538 to $760^{\circ} \mathrm{C}$. Both a uniaxial loading condition on conventional tensile specimens and a biaxial loading condition on pressurized tube specimens were included in this investigation. This study shows that creep and creep-rupture properties were changed significantly as a result of irradiation, and discusses possible explanations for the observed property changes.

\section{SUMMARY}

Fast reactor irradiation to a total fluence of $1 . \times 10^{22} \mathrm{n} / \mathrm{cm}^{2}$ at a temperature of $482{ }^{\circ} \mathrm{C}$ resulted in a significant degradation of the creep-rupture properties of Type 316 SS. High creep rates, possibly resulting from irradiation-induced precipitation, led to a substantial loss in rupture life at a 
test temperature of $538^{\circ} \mathrm{C}$. Low ductility, probably attributable to helium embrittlement, was responsible for reduced rupture 1 ife in the temperature range 593 to $760^{\circ} \mathrm{C}$.

Results from both uniaxial tests and biaxial tests showed similar changes in rupture life when comparisons were based on initial true stress. Because of substantial differences in initiai plastic strain between unirradiated and irradiated specimens, changes in rupture life measure in high-stress biaxial tests were substantially smaller when the comparison was made on the basis of engineering stress.

\section{EXPERIMENTAL PROCEDURE}

\section{MATERIALS}

The chemical composition of the two Type 316 ss used for the uniaxial and biaxial specimens are shown in Table 1 . The only significant differences in chemical composition between the two materials were in the carbon and manganese contents.

The material for uniaxial specimens was received as a $15.9 \mathrm{~mm}$ rod; this rod was reduced to a diameter of $7.75 \mathrm{~mm}$ by cold swaging with intermediate anneals at $1065^{\circ} \mathrm{C}$. In the final cold-swaging, the diameter was reduced from 7.75 to $6.86 \mathrm{~mm}$. The rod was given a final anneal at $1065^{\circ} \mathrm{C}$ for one hour, followed by a rapid air cool. The grain size of this material was ASTM 5 to 6 . Tensile specimens with a gage section diameter of $3.18 \mathrm{~mm}$ and a gage section length of $26.5 \mathrm{~mm}$ were then machined from the rod.

The test material for biaxial specimens was $5.3 \mathrm{~mm}$ diameter by $0.2 \mathrm{~mm}$ wall Type 316 ss tubing in the as-received condition. The as-received condition contains a small amount of cold work, which is shown by the following room temperature yield strength values for as-received and annealed $\left(1065^{\circ} \mathrm{C}\right.$, one hour) tube specimens : 
TABLE 1. Chemical Composition of Type 316 SS Used in Uniaxial and Biaxial CreepRupture Studies

Composition, wt:

\begin{tabular}{|c|c|c|c|}
\hline \multirow[t]{3}{*}{ Element } & \multicolumn{3}{|c|}{ Specimen Type } \\
\hline & \multicolumn{2}{|c|}{ Uniaxial } & \multirow[t]{2}{*}{ Biaxial } \\
\hline & (a) & (b) & \\
\hline C & 0.057 & 0.052 & 0.081 \\
\hline Mn & 1.80 & 1.72 & 1.51 \\
\hline $\mathrm{P}$ & 0.024 & 0.012 & \\
\hline$S$ & 0.014 & 0.020 & \\
\hline Si & 0.36 & 0.38 & 0.50 \\
\hline $\mathrm{Ni}$ & 13.39 & 13.55 & 13.25 \\
\hline $\mathrm{Cr}$ & 17.71 & 17.80 & 17.84 \\
\hline Mo & 2.26 & 2.33 & 2.32 \\
\hline $\mathrm{Cu}$ & 0.18 & 0.20 & 0.05 \\
\hline Co & 0.13 & 0.14 & \\
\hline $\mathrm{N}_{2}$ & & 0.041 & 0.039 \\
\hline $\mathrm{V}^{2}$ & & 0.04 & \\
\hline $\mathrm{Ti}$ & & 0.003 & \\
\hline Al & & 0.026 & \\
\hline B & & $<0.005$ & \\
\hline $\mathrm{O}_{2}$ & & 0.0178 & \\
\hline
\end{tabular}


Material Condition

As-received

Annealed
$0.2 \%$ Offset

Yield Strength, psi

38,000

39,000

33,400

33,800

The grain size of the as-received material is about ASTM 7-8. Biaxial stress-rupture specimens were composed of a section of the tubing to which appropriate fittings have been attached. This resulted in a test specimen having a length-to-diameter ratio of about 6 .

\section{IRRADI ATION}

The uniaxial and biaxial test specimens were sealed in Type 316 SS capsules in an environment of pure sodium containing 12 to $15 \mathrm{ppm} 0_{2}, 29 \mathrm{ppm} \mathrm{C}, 25 \mathrm{ppm}, \mathrm{Si}, 110 \mathrm{ppm} \mathrm{K}$, and $10 \mathrm{ppm} \mathrm{Ca}$. Boron, magnesium, manganese, and others were identified as being present in trace quantities. These capsules were placed in MK B-7 type tubes normally used for structural materials irradiation in EBR-II. An annular gas gap filled with a $30 \% \mathrm{He}-70 \%$ Ar mixture was used in conjunction with nuclear heating to achieve an irradiation temperature estimated to be $\sim 482^{\circ} \mathrm{C}$. This estimate was based on heat transfer calculations using best available information on reactor sodium temperature for the assembly, experiment geometry, and reactor gamma heat ( $0.84 \mathrm{~W} / \mathrm{g}$ ). However, the observed microstructure and the postirradiation tensile properties for the rod specimens, when compared with other irradiated materials, indicated the irradiation temperature had been $540^{\circ} \mathrm{C}$ or higher. Irradiations were conducted in position 7C4 of EBR-II within the core region. Both sets of specimens were irradiated to a fluence of $1.2 \times 10^{22} \pm 15 \%$ (tota1) $\left[1.0 \times 10^{22} \mathrm{n} / \mathrm{cm}^{2}\right.$ $(\mathrm{E} .>0.1 \mathrm{MeV})]$. The irradiation period was equivalent to $127 \mathrm{fu} 11$ 
power days ( 3045 hours). After irradiation, the sodium environment was removed by dissolving and rinsing with water followed by rinsing with ethyl alcohol for drying purposes.

\section{TEST METHODS}

The basic standard for test procedure was the ASTM tentative recommended practice for conducting creep and time-forrupture tension tests of materials, ASTM E139-66T (revised 1966). Uniaxial and biaxial stress tests were conducted within the recommended ASTM specifications for temperature and stress. Uniaxial tests were conducted within the ASTM recommendations for alignment.

All uniaxial tests were conducted in an inert gas (helium or argon) environment. The test procedure allowed 20 hours for heatup and thermal stabilization prior to applying the creep load. Specimen extension was monitored during the test by measuring pull-rod motion with a dial indicator. Total elongations were obtained in two ways. One value was obtained by post-test measurement of specimen length and a second value was estimated from the strain-time curves.

Biaxial stress-rupture tests were conducted in an argon atmosphere by internally pressurizing unrestrained thin-wall tubes with argon gas and holding pressure constant until rupture occurred. Under these conditions, the initial hoop stress to axial stress ratio is 2 . Maximum engineering hoop stress was determined using the formula for thin wall cylinders:

$$
\sigma=\frac{P D}{2 t}
$$

where $P=$ internal gas pressure

$D=$ original inside diameter of tube

$t=$ original minimum wall thickness of tube.

Tests were conducted by attaching the tubular cladding specimen to a test rig through the use of standard tube fittings, 
placing the assembled specimen-test rig in a heated furnace, and applying the desired pressure after the specimen had stabilized ( $\sim 4$ hours) at the desired test temperature.

Diametral strain for biaxial stress-rupture tests were not measured at the point of maximum strain on fragmented test pieces to avoid confusing uniform strain with strain which is related to sudden gas expulsion at the time of failure. It was empirically determined that a diameter measurement taken halfway between the ruptured area and the end fitting, using the longest part of the fragmented specimen, gave a reasonably good value of uniform strain.

The uniaxial and biaxial tests were conducted at constant load and pressure, respectively. At particular test temperatures and stresses, substantial plastic straining occurred during initial application of load (pressure). The increased flow stress of irradiated material reduced the initial strain on loading with respect to the strain obtained on loading an unirradiated specimen. This difference in initial strain resulted in a lower true stress in irradiated specimens than in unirradiated specimens with identical loads (pressure). All comparisons were therefore based on true initial stress.

True initial stress values for uniaxial tests were calculated as $\sigma_{0}\left(1+\varepsilon_{L}\right)$, where $\sigma_{0}$ is the engineering creep stress and $\varepsilon_{L}$ is the engineering strain in a fully loaded creep specimen. Values of $\varepsilon_{L}$ were determined from tensile tests at each temperature on both irradiated and unirradiated specimens.

The relationship of strain in the biaxially loaded specimen to the internal gas pressure during loading was determined by subjecting a specimen to an ascending series of test pressures, holding for one minute period, and measuring the strain produced. A stress-strain curve was constructed, as shown in Figure 1 . 


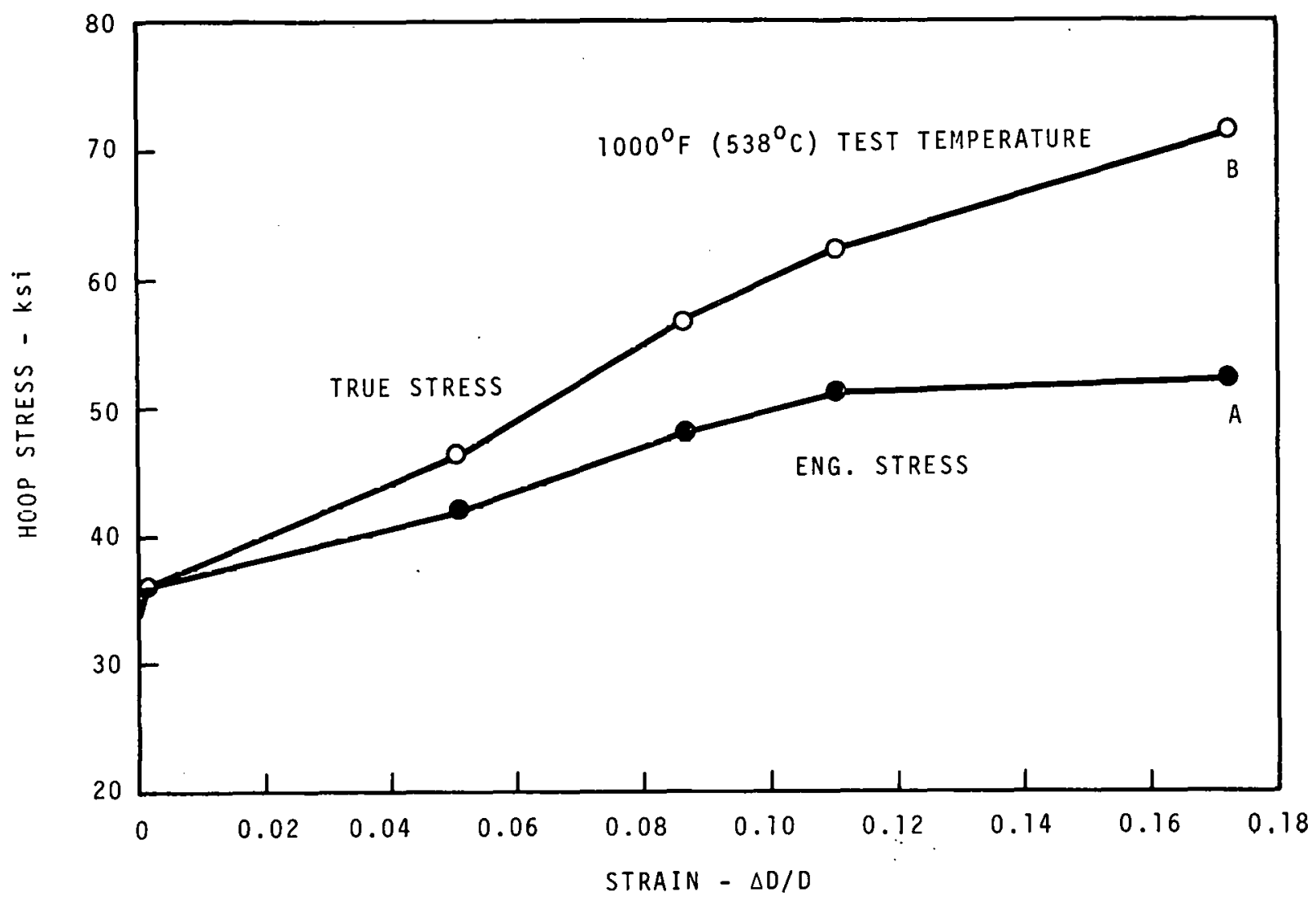

FIGURE 1. Hoop Stress-Strain Curve for $5.3 \mathrm{~mm}$ Diameter $x 0.2 \mathrm{~mm}$ Wall Type 316 ss Subjected to Internal Pressure

Curve $A$ is the engineering stress, $\sigma_{0}$, based on original dimensions, and Curve $B$ is the true stress, calculated as $\sigma_{0}(1+\varepsilon)^{2}$, where $\varepsilon$ is the engineering diametral strain. In each test, the instantaneous strain is obtained from Line $A$ and the true stress is obtained from line $B$ for that strain.

Attempts to establish Curves $\mathrm{A}$ and $\mathrm{B}$ at $538{ }^{\circ} \mathrm{C}$ on irradiated tubes which show low initial strain indicated there was very little difference in the true and engineering hoop stress, thus engineering initial hoop stress was used for all biaxial tests on irradiated tubes.

The average creep rate of biaxial test specimens was evaluated by separating the strain caused by creep and the strains associated with initial load-up and with the geometric changes 
during creep. The creep component of the total strain was obtained by first determining the final true hoop stress, $\sigma_{0}\left(1+\varepsilon_{r}\right)^{2}$, from the rupture strain, $\varepsilon_{r}$, and using this stress in conjunction. with Line $B$ of Figure 1 to determine the tensile strain, $\varepsilon_{t}$. Then $\varepsilon_{t}$ was subtracted from $\varepsilon_{r}$ to obtain $\varepsilon_{c}$, the creep strain. For the low strain obtained in the irradiated tubes, $\varepsilon_{c}$ was assumed to be equal to $\varepsilon_{r}$. Average creep rate values were then calculated by dividing the creep strain, $\varepsilon_{c}$, by the rupture time.

\section{RESULTS}

\section{RUPTURE LIFE}

The uniaxial creep and creep-rupture results for tests determined at 538, 593, 649, and $760{ }^{\circ} \mathrm{C}$ are given in Table 2 . The stress dependence of rupture life is shown on a conventional $10 \mathrm{~g}$ stress-10g rupture time plot in Figure 2. In general, the curve plotted for the irradiated specimens is parallel, or nearly parallel, to the curve for unirradiated specimens, except at $593{ }^{\circ} \mathrm{C}$ where the rupture life of irradiated specimens exhibits a somewhat higher stress dependence than does the rupture life of unirradiated specimens. The rupture life of all irradiated specimens was reduced when compared to unirradiated control material. The reduction in rupture life at $538{ }^{\circ} \mathrm{C}$ was about a factor of 1/20. Losses in rupture 1 ife at 593 and $649^{\circ} \mathrm{C}$ were less severe, with reductions by factors of $1 / 5$ to $1 / 2$ and $1 / 2$, respectively. At $760^{\circ} \mathrm{C}$, the reduction in rupture 1 ife was about a factor of $1 / 7$.

Biaxial stress-rupture results on the as-received material determined at 538,649 , and $760^{\circ} \mathrm{C}$ are given in Table 3 . These results are in reasonable agreement with stress-rupture data published by other experimenters. $(1,2)$ The results determined at the same temperatures for irradiated material are given in Table 4 . 
TABLE 2. Uniaxial Creep-Rupture Data for Type 316 sS Irradiated in EBR-II (a) to $1.2 \times 10^{22} \mathrm{n} / \mathrm{cm}^{2}$ (total) at $2900{ }^{\circ} \mathrm{F}\left(482^{\circ} \mathrm{C}\right.$ )

\begin{tabular}{|c|c|c|c|c|c|c|c|c|c|}
\hline \multirow{2}{*}{$\begin{array}{l}\text { Test } \\
\text { Temp, } \\
{ }^{\circ} \mathrm{C} \\
\end{array}$} & \multirow{2}{*}{$\begin{array}{c}\text { Eng. } \\
\text { Stress, } \\
\text { ksi } \\
\end{array}$} & $\begin{array}{c}\text { True } \\
\text { Stress } \\
\end{array}$ & \multirow{2}{*}{$\begin{array}{l}\text { Init. } \\
\text { ksi } \\
\text { Control }\end{array}$} & \multirow{2}{*}{$\begin{array}{l}\text { Minimum } \\
\times 105 \\
\text { Irrad. }\end{array}$} & \multirow{2}{*}{$\begin{array}{l}\text { Creep Rate } \\
\text { in./in, /hr } \\
\text { Contro1 }\end{array}$} & \multirow{2}{*}{$\begin{array}{l}\text { Rupture } \\
\text { Irrad. }\end{array}$} & \multirow{2}{*}{$\frac{\text { Time, } \mathrm{hr}}{\text { Control }}$} & \multicolumn{2}{|c|}{$\begin{array}{l}\text { Total } \\
\text { Elongation }\end{array}$} \\
\hline & & Irrad. & & & & & & Irrad. & Control \\
\hline $\begin{array}{l}538 \\
538 \\
538 \\
538 \\
538 \\
538\end{array}$ & $\begin{array}{l}55 \\
50 \\
45 \\
40 \\
36 \\
30\end{array}$ & $\begin{array}{l}60.2 \\
53.0 \\
47.1 \\
41.1 \\
36.7 \\
30.5\end{array}$ & $\begin{array}{l}64.2 \\
56.5 \\
49.5 \\
43.1 \\
38.1 \\
30.6\end{array}$ & $\begin{array}{r}107.0 \\
31.9 \\
24.2 \\
6.3 \\
1.0 \\
20.1\end{array}$ & $\begin{aligned} & 9.3 \\
& 3.3 \\
& 1.4 / 2.7 \\
& 0.8 \\
& 20.27 \\
& 20.06(\mathrm{~d})\end{aligned}$ & $\begin{array}{r}26.7 \\
85.2 \\
107.8 \\
149.6(\mathrm{c}) \\
>673.5 \\
\text { On Test }\end{array}$ & $\begin{array}{r}263 \\
433 \\
1032 \\
2795\end{array}$ & $\begin{array}{l}17.6 \\
12.3 \\
5.8 \\
3.7(b)\end{array}$ & $\begin{array}{l}38.9 \\
18.2 \\
15.4 \\
14\end{array}$ \\
\hline $\begin{array}{l}593 \\
593 \\
593 \\
593 \\
593\end{array}$ & $\begin{array}{l}45 \\
40 \\
36 \\
30 \\
26\end{array}$ & $\begin{array}{l}46.8 \\
40.6 \\
36.6 \\
30.2 \\
26.1\end{array}$ & $\begin{array}{l}50.0 \\
43.3 \\
38.4 \\
31.2 \\
26.7\end{array}$ & $\begin{array}{r}489.0 \\
68.6 \\
23.2 \\
4.7 \\
0.9\end{array}$ & $\begin{array}{l}250.0 \\
4.4 / 34.2 . \\
\sim 26.7 \text { (d) } \\
\sim 5.2(\mathrm{~d}) . \\
\sim 1.5\end{array}$ & $\begin{array}{l}11.5 \\
45.5 \\
202.8(\mathrm{c}) \\
>1489 \text { ( } \\
\text { On Test }\end{array}$ & $\begin{array}{r}23 \\
200 \\
236\end{array}$ & $\begin{array}{r}14.1 \\
7.9 \\
8.0\end{array}$ & $\begin{array}{l}\sim 25.1 \\
25 \\
20.9\end{array}$ \\
\hline $\begin{array}{l}649 \\
649 \\
649 \\
649\end{array}$ & $\begin{array}{l}30 \\
28 \\
25 \\
22\end{array}$ & $\begin{array}{l}30.3 \\
28.1 \\
25.1 \\
22.1\end{array}$ & $\begin{array}{l}31.1 \\
28.8 \\
25.5 \\
22.2\end{array}$ & $\begin{array}{r}\sim 84.5 \\
\sim 42.8 \\
\sim 25.0 \\
10.1\end{array}$ & $\begin{array}{r}212.0 \\
94.4 \\
63.8 \\
15.9\end{array}$ & $\begin{array}{r}56.8 \\
\sim 130 \\
262 \\
\sim 800\end{array}$ & $\begin{array}{r}95 \\
168 \\
375 \\
1295\end{array}$ & $\begin{array}{l}\sim 13^{(b)} \\
\sim 19^{(b)}\end{array}$ & $\begin{array}{r}\sim 50 \\
51 \\
66 \\
35\end{array}$ \\
\hline $\begin{array}{l}760 \\
760 \\
760 \\
760\end{array}$ & $\begin{array}{l}17 \\
15 \\
12 \\
10\end{array}$ & $\begin{array}{l}17 \\
15 \\
12 \\
10\end{array}$ & $\begin{array}{l}17.1 \\
15 \\
12 \\
10\end{array}$ & $\begin{array}{r}948 \\
\sim 222.0 \\
66 . \\
23.2\end{array}$ & $\begin{array}{l}878 \\
460 / 412 \\
90.4 \\
28.5\end{array}$ & $\begin{array}{r}9.3 \\
20.1 \\
55.1 \\
146.5\end{array}$ & $\begin{array}{r}28 \\
72 \\
246 \\
1050\end{array}$ & $\begin{array}{l}\sim 8.8^{(b)} \\
7.2(\mathrm{~b}) \\
\sim 4.5 \\
5.3\end{array}$ & $\begin{array}{l}72 \\
70 \\
64 \\
59\end{array}$ \\
\hline
\end{tabular}

a. AlZ tests in inert gas

b. Estimated from creep curve

c. Test stopped before rupture

d. Extrapolated value 


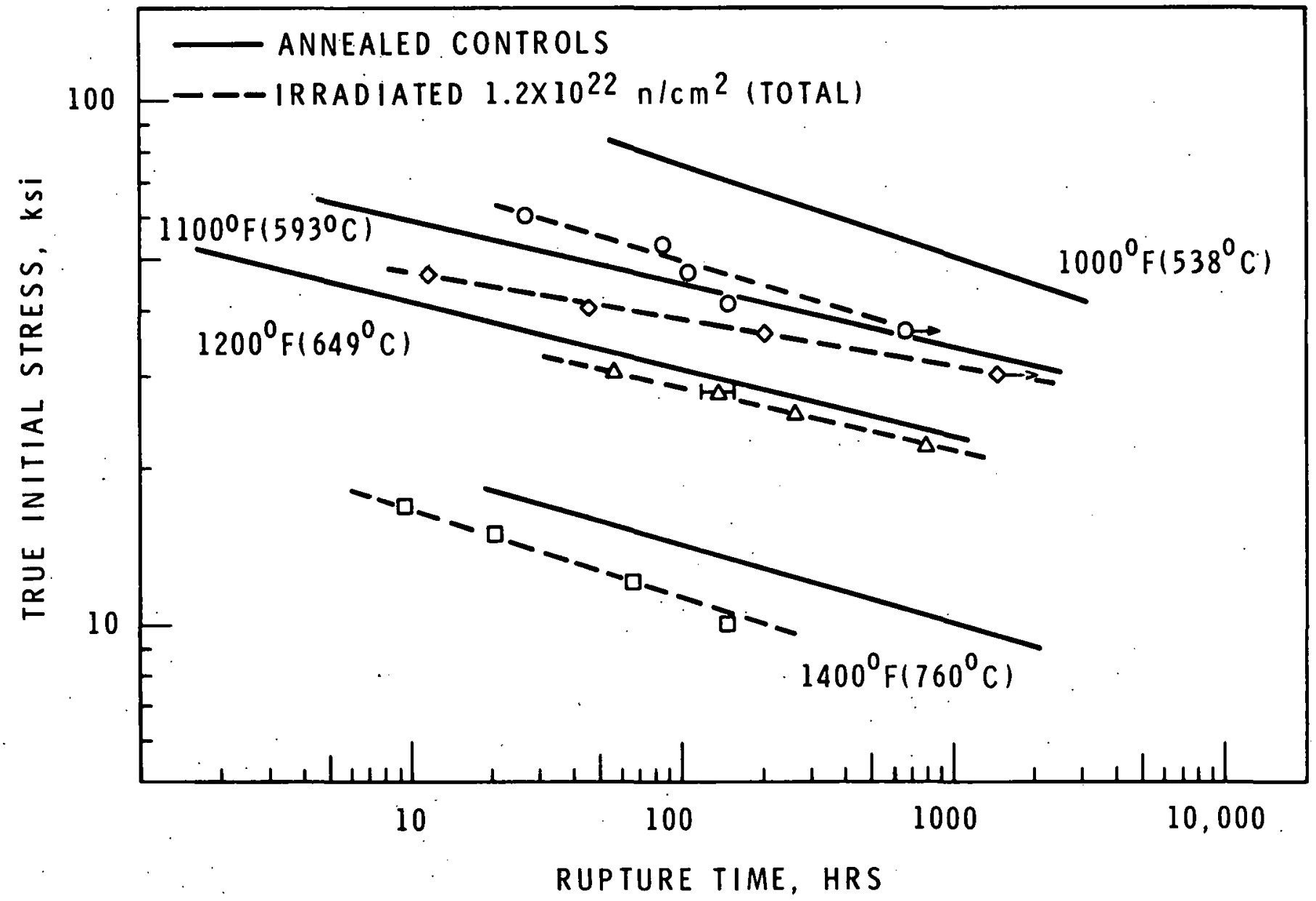

FIGURE 2. Effect of EBR-II Irradiation on the Rupture Life 
TABLE 3. Biaxial Stress-Rupture Data for Type 316 SS Tes?

Temp, Hoop Stress, ksi Rupture Ductility; Average Creep Rate $\frac{{ }^{\circ} \mathrm{C}}{538} \frac{\text { Eng. }}{52.0} \frac{\text { Tr. Init. }}{71.0} \frac{\text { Time, hr }}{0.1} \frac{\Delta \mathrm{D} / \mathrm{D}, \mathrm{O}_{0}^{\circ}}{\text { N.A. }}$ $\frac{\mathrm{x} 105 \text {, in./in./hr }}{\text { N.A. }}$

$538 \quad 51.0$

62.0

6.0

17.0

$538 \quad 49.0$

58.7

79.0

$538 \quad 48.0$

56.7

55.0

21.0

117.0

538

46.7

545.0

14.0

46.8

$538 \quad 38.0$

44.8

1681.0

13.0

54.6

$\begin{array}{ll}649 & 38.5\end{array}$

44.0

0.5

8.7

10.1

649

31.5

33.0

5.8

16.5

2.56

649

31.4

12.0

649

30.0

15.0

$649 \quad 25.5$

26.0

70.0

24.0

875.0

20.0

385.0

18.0

3470.0

17.0

1230.0

6.2

1120.0

64920.0

27.0

$\begin{array}{ll}760 & 26.0\end{array}$

20.0

0.4

6.8

18.0

10.0

17.0

16.0

13.9

42.0

9.6

300.0

5.8

450.0

8.6

4.8

225.0

370.0

46.0

13.0

127.0

1.9

3.6

6.7

1.93

14.3

115.0

$760 \quad 13.9$

6.5

1981.0

24.0

4350.0

2000.0

1400.0

800.0

512.0

9.1

31.0

760

6.5

6.5

9.6

4.8 
TABLE 4. Biaxial Stress-Rupture Data for Type $316 \mathrm{ss}$ Irradiated in EBR-II to $1.2 \times 10^{22} \mathrm{n} / \mathrm{cm}^{2}$ (total) at $\sim 900^{\circ} \mathrm{F} \cdot\left(482^{\circ} \mathrm{C}\right)$

Test

Temp, Eng. Hoop (a) Rupture Ductility, Average Creep Rate

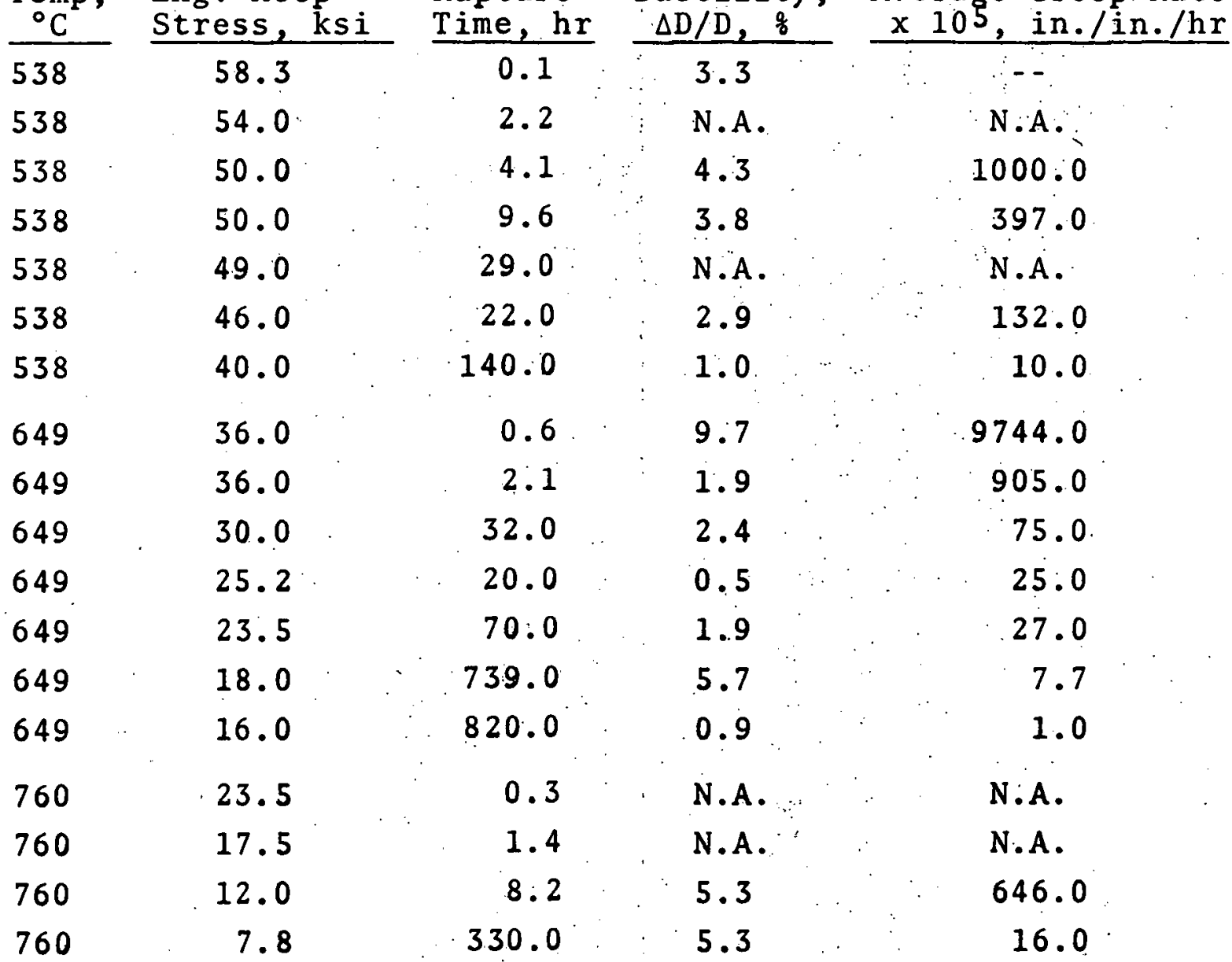

a. Engineering and true stress assumed to be the same for irradiated tubes 
The biaxial stress-rupture data is plotted as log stress against log rupture time, in Figure 3 . It was found that the irradiation reduced the rupture life of the Type 316 SS, when tested under biaxial stress conditions, at each of the test temperatures. At $538{ }^{\circ} \mathrm{C}$, the reduction in rupture life is about a factor of $1 / 40$. The decrease in rupture life at $649{ }^{\circ} \mathrm{C}$ was only a factor of $1 / 2$, while at $760{ }^{\circ} \mathrm{C}$, the reduction in rupture life was about a factor of $1 / 10$.

\section{TEMPERATURE-COMPENSATED RUPTURE LIFE}

The uniaxial data and the biaxial data are presented in Figures 4 and 5 on $\log$ stress-log $\theta$ plots, where $\theta$ is defined as

$$
\theta=t_{r} \exp \left(-\frac{Q}{R T}\right)
$$

where $t_{r}$ is rupture life in hours

$Q$ is activation energy in calories/mole

$\mathrm{T}$ is absolute temperature in ${ }^{\circ} \mathrm{K}$

$R$ is gas constant in calories/mole-degree.

Results from preirradiation and postirradiation tests correlate well with a $Q$ value of 95,000 calories/mole in both the uniaxial and biaxial tests. Since only two of the $538{ }^{\circ} \mathrm{C}$ uniaxial tests (at engineering stresses of 45 and $40 \mathrm{ksi}$ ) on irradiated specimens fall short of the curve; even within the $538{ }^{\circ} \mathrm{C}$ test series, it appears that these specimens failed prematurely. The temperature-compensated rupture life plots in Figures 4 and 5 clearly show the large reduction in rupture life at $538{ }^{\circ} \mathrm{C}$, the lesser reductions at 593 and $649^{\circ}{ }^{\circ} \mathrm{C}$, and the larger losses again at $760^{\circ} \mathrm{C}$.

\section{CREEP RATES}

The minimum creep rates determined in uniaxial tests on both irradiated and unirradiated material are given in Table 2 . The results are plotted as $10 \mathrm{~g}$ creep rate against log stress 


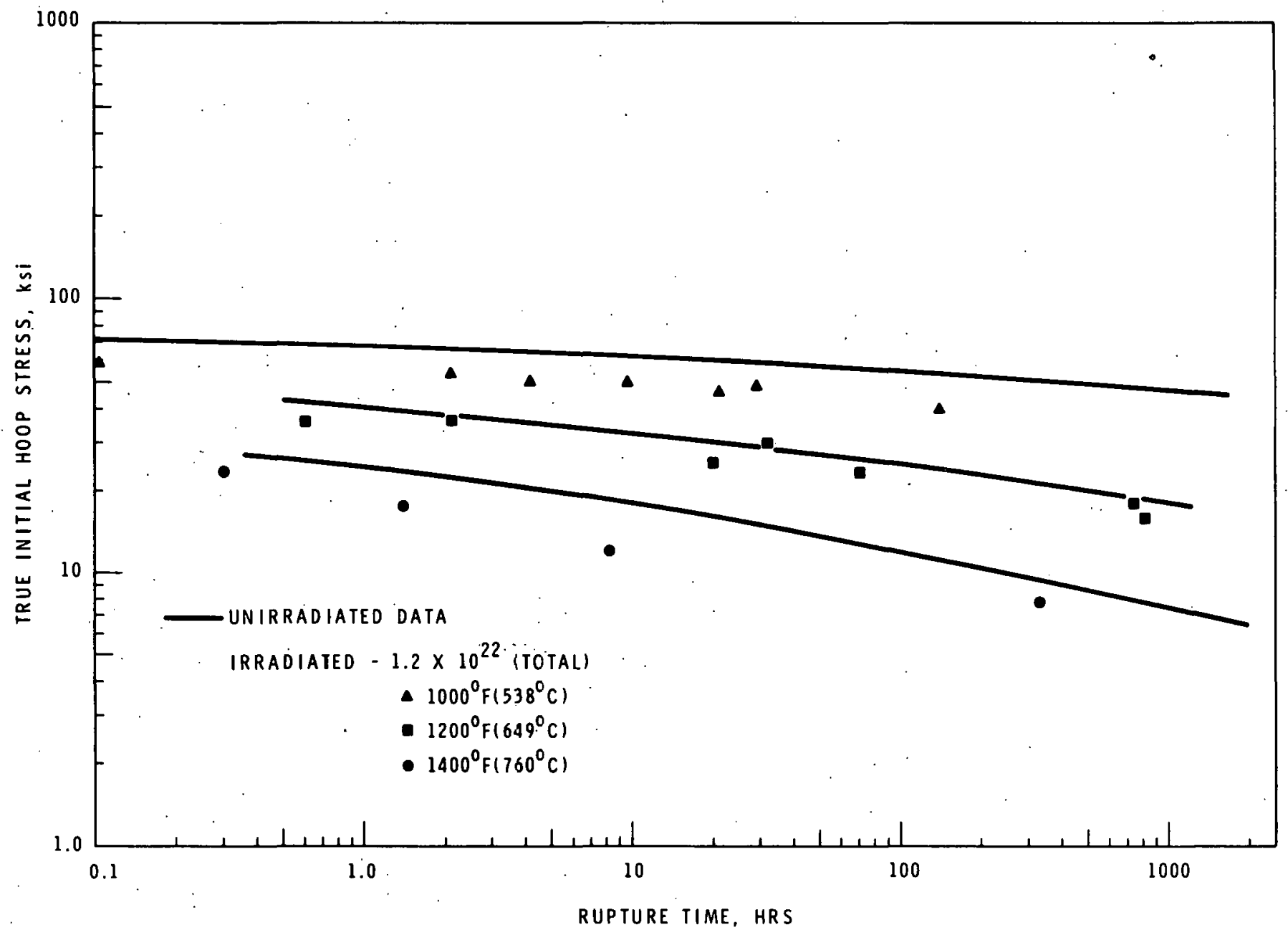

FIGURE 3. Effect of EBR-II Irradiation on the Rupture Life of Type 316 SS Determined in Biaxial Tests 


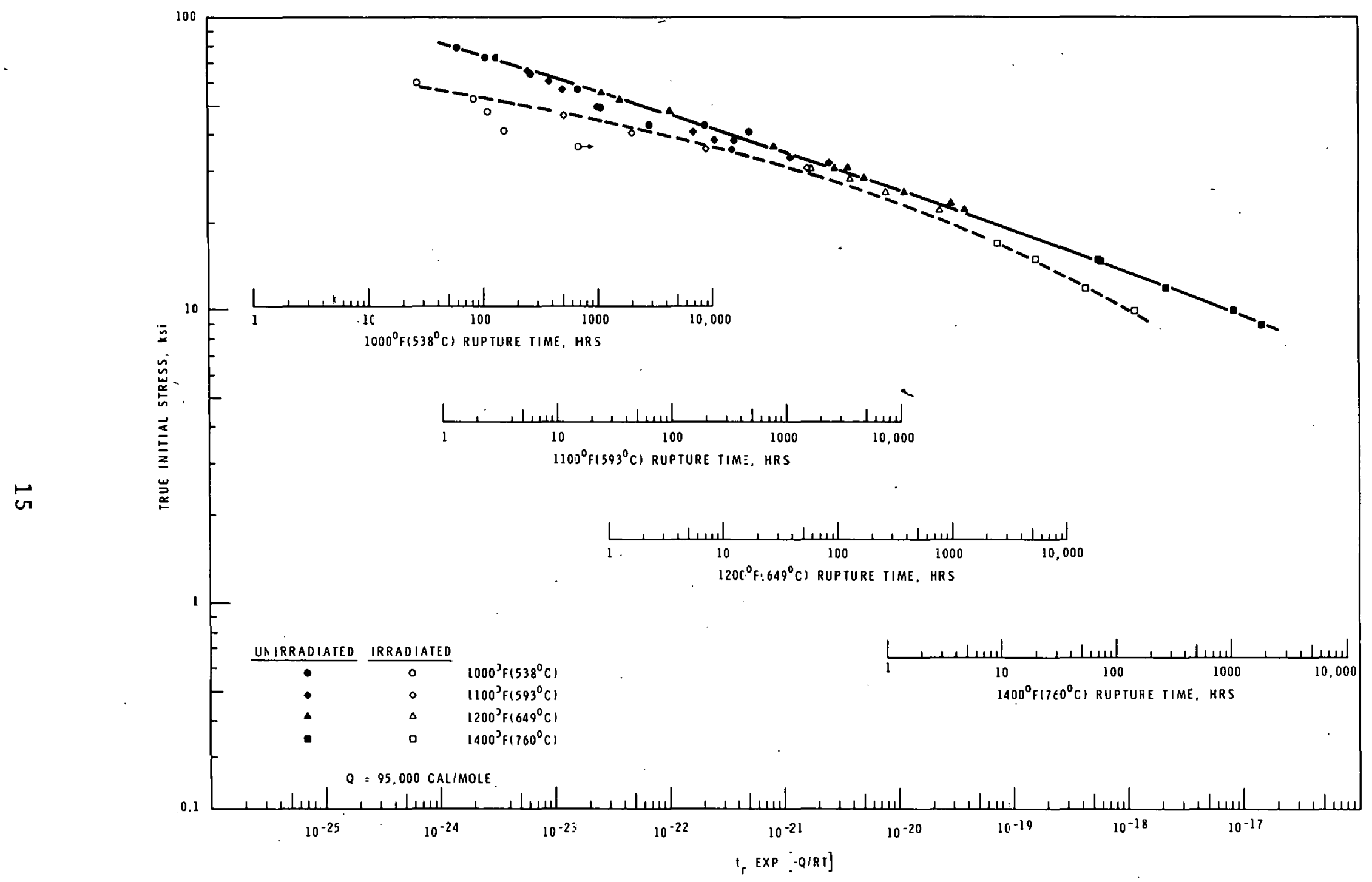

FIGURE 4. Effect of EBR-II Irradiation on the Theta Correlation of Uniaxial Test Results on Type 316 SS 


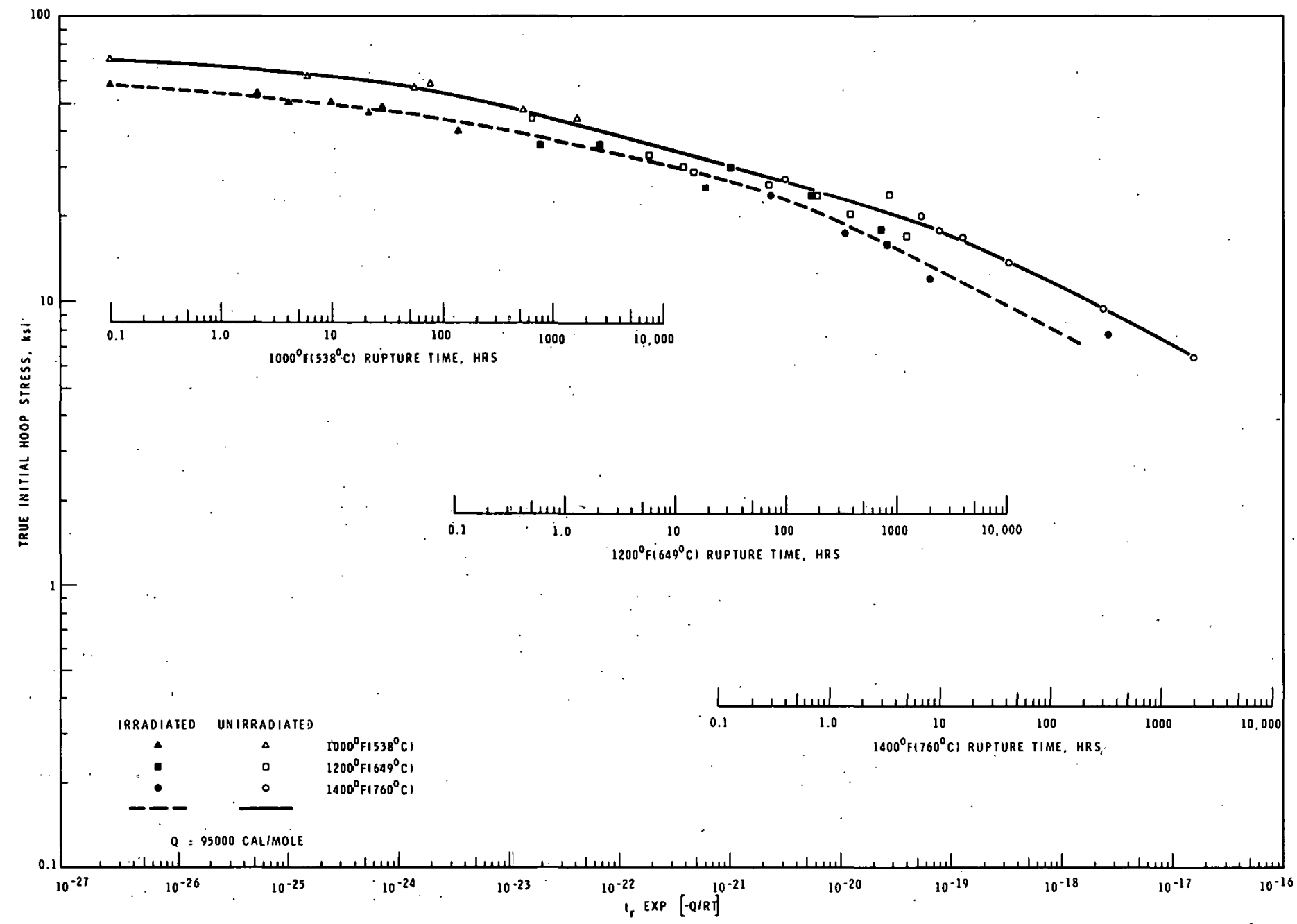

FIGURE 5. Effect of EBR-II Irradiation on the Theta correlation of Biaxial Test Results on Type 316 SS 
in Figure 6. The creep rate was found to increase significantly (i.e., by up to factor of 10 ) after irradiation for tests at $538^{\circ} \mathrm{C}$. The stress dependence of minimum creep rate appeared to be higher for irradiated material at this temperature. The magnitude and stress dependence of minimum creep rate do not appear to be changed significantly at test temperatures of 593, 649 , and $760{ }^{\circ} \mathrm{C}$.

Average creep rates determined from biaxial tests are presented graphically in Figure 7 . These results also showed higher creep rates in irradiated material at a test temperature of $538 .{ }^{\circ} \mathrm{C}$. The creep rates of irradiated specimens at $649{ }^{\circ} \mathrm{C}$ were virtually the same as the unirradiated values. Although the data at $760^{\circ} \mathrm{C}$ is quite limited, it appeared that irradiated creep rate values were again higher than unirradiated values.

\section{DUCTILITY}

Strain at rupture in both uniaxial tests (see Table 2) and biaxial tests (see Tables 3 and 4 ) was reduced by irradiation. The lowest strains observed were about $5 \%$ for uniaxial tests and about $1 \%$ for biaxial tests. Comparison of the uniaxial strain-time curves revealed that both second stage creep strain and third stage creep strain are reduced in irradiated material at temperatures of $593^{\circ} \mathrm{C}$ and above. Although the creep strains may be somewhat lower in irradiated material tested at $538{ }^{\circ} \mathrm{C}$, the major factor affecting ductility at this temperature was reduced plastic strain on loading.

\section{DISCUSSION}

The results of this investigation show that fast reactor irradiation produces nearly the same changes in rupture life in uniaxial tests and in biaxial tests. This agreement between the two sets of test results shows that the basic material behavior is similar in both types of tests. However, it is important to emphasize that this conclusion is based on the 


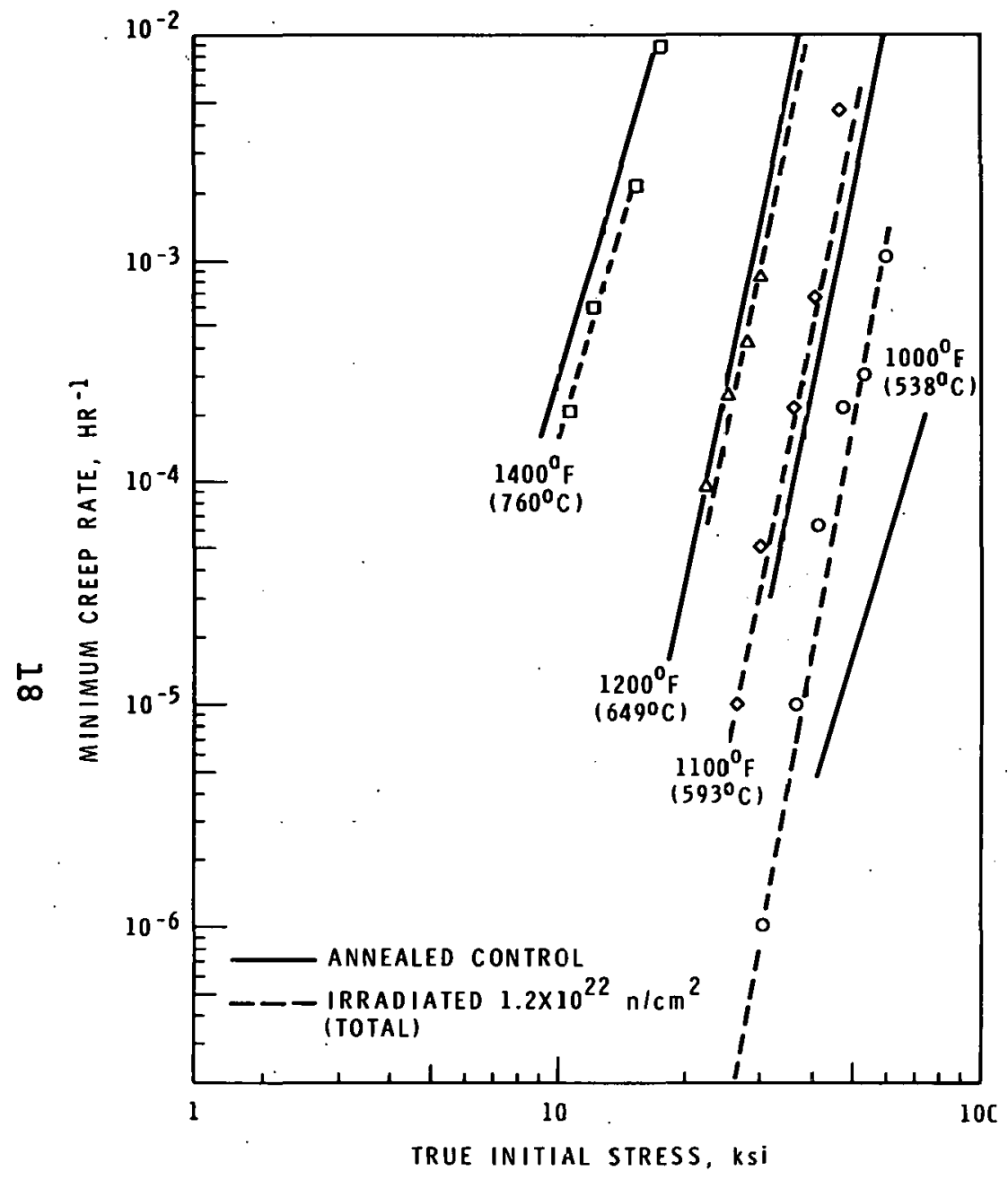

FIGURE 6. Effect of EBR-II Irradiation on the Minimum Creep Rate of Type 316 SS Determined in Uniaxial Tests

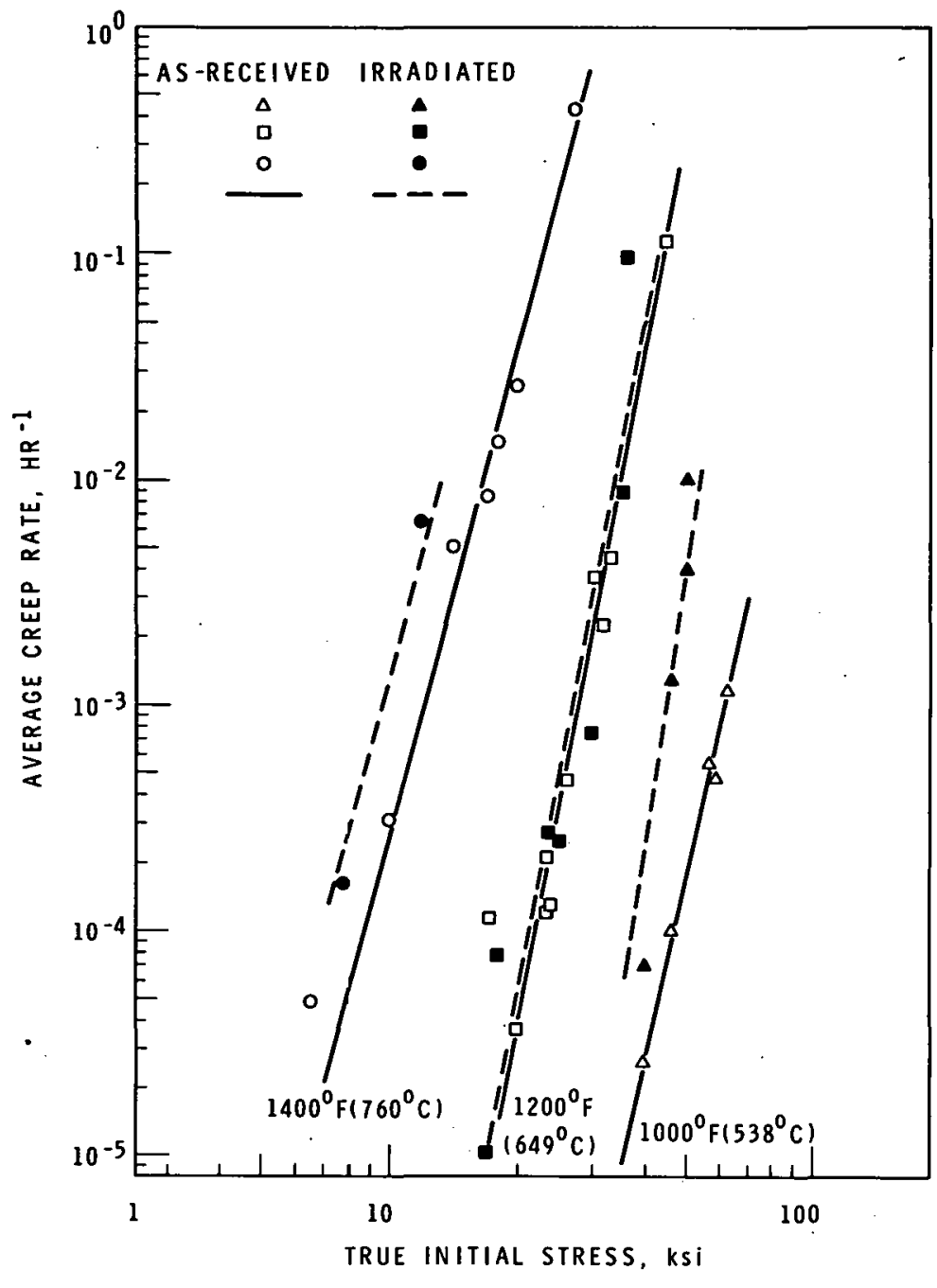

FIGURE 7. Effect of EBR-II Irradiation on Average Creep Rate of Type 316 SS Tube Determined in Biaxial Tests 
the use of initial true stress in comparing results from unirradiated specimens with results from irradiated specimens. If comparisons are based on engineering stress, then uniaxial tests and biaxial tests do not show the same losses in rupture life at high stresses. For example, it was found that the reduction in rupture life at $538{ }^{\circ} \mathrm{C}$, based on intital true stress, was about a factor of $1 / 40$ in biaxial tests. If results for tests are compared on the basis of engineering stress, it is found that there is essentially no difference in rupture life at $538{ }^{\circ} \mathrm{C}$. On the other hand, the reduction in rupture life in $538{ }^{\circ} \mathrm{C}$ uniaxial tests changes from a factor of $1 / 20$ to a factor of $1 / 10$ when the basis of comparison changes from initial true stress to engineering stress. Thus the differences in initial plastic strain between irradiated and unirradiated specimens are significant in evaluating rupture life losses, particularly in the case of high-stress biaxial tests. The use of engineering stress results in a significant apparent difference between uniaxial and biaxial test results. However, the use of initial true stress provides a precise correlation for the data.

Fast reactor irradiation can also affect the creep properties of Type 316 SS as evidenced by the increased creep rates measured in irradiated specimens at $538^{\circ} \mathrm{C}$. Both the minimum creep rate values determined in uniaxial tests and the average creep rate values determined in biaxial tests show the increased creep rate. At a temperature of $538^{\circ} \mathrm{C}$ there was very little primary or tertiary creep strain, so the average creep rate in biaxial tests should be a good approximation of the actual minimum creep rate. Minimum creep rates at 593, 649, and $760^{\circ} \mathrm{C}$ were apparently not significantly affected by irradiation; however, the average creep rate values indicate that irradiation does not affect creep rates in $649{ }^{\circ} \mathrm{C}$ tests, but leads to increased creep rates in $760^{\circ} \mathrm{C}$ tests. The 
apparent discrepancy between the uniaxial test and the biaxial test in reflecting creep rate changes at $760^{\circ} \mathrm{C}$ probably results because the average creep rate is no longer a good approximation of the actual minimum creep rate. Uniaxial tests on the unirradiated tubular material at $760^{\circ} \mathrm{C}$ indicated there was substantial primary creep strain; however, this primary creep strain is included as linear creep strain in computing average creep rates from the diametrai strains. When primary creep becomes significant, it is quite possible to obtain higher average creep rate values for irradiated specimens, even though the actual minimum creep rate is the same in both irradiated specimens and unirradiated specimens.

Standring et al ${ }^{(1)}$ have reported results on tubes irradiated in DFR and tested in a biaxial stress mode. They observed decreased rupture life for a given effective initial hoop stress, decreased ductility, and no change in average creep rate for tests at $650{ }^{\circ} \mathrm{C}$. The results observed in biaxial tests in the present study at $649{ }^{\circ} \mathrm{C}$ are in qualitative agreement with these results. Creep-rupture tests on uniaxial specimens after fast reactor irradiation in DFR have been reported by weisi et al (3) These observations indicated testing at $700^{\circ} \mathrm{C}$ after irradiation at $600{ }^{\circ} \mathrm{C}$ to a total fluence of $1.6 \times 10^{22} \mathrm{n} / \mathrm{cm}^{2}$ resulted in increased minimum creep rates. The results in the present study for uniaxial tests at 649 and $760^{\circ} \mathrm{C}$ indicated little if any change in the minimum creep rate. The exact cause of the variance between the two sets of data is not clear, but quite possibly was related to differences in the irradiation temperature, alloy composition, and/or fluence.

A clear picture of the mechanism responsible for the increased creep rates at $538{ }^{\circ} \mathrm{C}$ has not yet emerged, but several possible explanations are currently being evaluated. One consideration is that the increased creep rate is a result of 
irradiation-induced precipitation that has been observed in the as-irradiated uniaxial material. (4) A current investigation ${ }^{(5)}$ of unirradiated, thermally aged specimens of the uniaxial test material does indeed indicate that for aging temperatures above $600{ }^{\circ} \mathrm{C}$ extensive precipitation can lead to increased creep rates similar to those observed in irradiated specimens. Although the relationship between the structure and the creep rate in material which has undergone extensive second phase precipitation is not yet established, the present evidence identifies irradiation-induced precipitation as one explanation of the increased creep rates.

Another possible explanation for the creep behavior centers on the irradiation-induced defect structure. Transmission electron microscopy observations showed a low density of voids and dislocations in the as-irradiated uniaxial test material. Increased creep rates could result if this substructure somehow leads to an increased density or increased velocity of mobile dislocations during creep. At higher test temperatures, increased creep rates may not be observed if the substructure annealed out before beginning the creep test. At the present time, there is no direct evidence or detailed theory to support these hypotheses. However, several irradiated specimens have been annealed for 50 hours at $649{ }^{\circ} \mathrm{C}$ before creep testing at $538^{\circ} \mathrm{C}$. These specimens still exhibited higher creep rates than unirradiated specimens, so a simple picture of radiation-damage annealing is apparently an inadequate explanation of the observed effects. Also, current studies(5) of this same alloy continue to show increased creep rates at $538{ }^{\circ} \mathrm{C}$ over quite a wide range of irradiation temperatures and fluences. Therefore, if the observed creep behavior is directly related to the irradiation-induced defect structure, the relationship is apparently a complex one. 
The magnitude of rupture life loss after irradiation depends on test temperature, and is related to the changes in creep rates and to reduced ductility. At $538^{\circ} \mathrm{C}$, the substantial loss in rupture life was primarily a result of the high creep rates, and the contribution from any ductility loss was relatively sma11. However, at temperatures of 593,649 , and $760{ }^{\circ} \mathrm{C}$, the losses in rupture life resulted from reduced ductility (i.e., reduced second stage and third stage creep strains), with no significant contribution from creep rate differences. The ductility loss was most severe at $760^{\circ} \mathrm{C}$, and, correspondingly, a larger reduction in rupture life was observed at this temperature. The underlying cause of the low ductility at these higher temperatures was undoubtedly associated with a helium embrittlement mechanism, perhaps operating in conjunction with effects produced by the defect structure and second-phase precipitations. 


\section{REFERENCES}

1. J. Standring, I. P. Be Zl, H. Tickel, and A. Glendinning. 'Effects of Neutron Irradiation on Creep-Rupture Properties of Type 316 stainless Steel Tubes," "Irradiation Effects in Structural AZloys for Thermal and Fast Reactors," Am. Soc. Testing Mater. Spec. Tech. Publ., vol. 457, pp. 414428 . 1969 .

2. W. T. Lee. Biaxial Stress-Rupture Properties of Austenitic Stainless Steels in Static Sodium, A-1-AEC-12694. June 1968 .

3. M. Weisz, J. Malkin, J. Erler, and J. P. Andre. 'High Temperature Embrittiement of AISI Type 316 Austenitic Stainless Steels After Irradiation," "Irradiation Effects in Structural Alzoys for Thermal and Fast Reactors," Am.

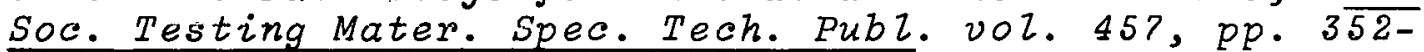
370. 1969 .

4. H. R. Brager, and H. E. Kissinger. "Irradiation-Induced Precipitation in Type 316 Stainless Steel," Trans, Am. Nucl. Soc., vol. 12, p. 118. 1969.

5. A. J. Lovelz, and L. D. Blackburn. Unpublished Data. WADCO Corporation, Richland, Washington. (To be published) 


\section{DISTRIBUTION}

No. of

Copies

OFFSITE

AEC Chicago Patent Group

G. H. Lee

AEC Division of Reactor Development and Technology

Director, RDT

Asst Dir for Nuclear Safety

Analysis \& Evaluation $\mathrm{Br}$, RDT:NS

Asst Dir for Plant Engrg, RDT

Facilities $\mathrm{Br}$, RDT: $\mathrm{PE}$

Components $\mathrm{Br}, \mathrm{RDT}: \mathrm{PE}$

Instrumentation \& Control Br, RDT:PE

Liquid Metal Systems, $\mathrm{Br}$, RDT : PE

Asst Dir for Program Analysis, RDT

Asst Dir for Project Mgmt, RDT

Liquid Metals Projects $\mathrm{Br}$, RDT : PM

G. J. Mishko

FFTF Project Manager, RDT:RE

Asst Dir for Reactor Engrg, RDT

Contro1 Mechanisms $\mathrm{Br}$, RDT:RE

Core Design Br, RDT:RE (2)

Fuel Handling $\mathrm{Br}$, RDT : RE

Reactor Vessels, $\mathrm{Br}$, RDT:RE

Coolant Chemistry $\mathrm{Br}$, R.DT:RT

Fuel Recycle Br, RDT:RT

Fuels \& Materials $\mathrm{Br}$, RDT:RT

Reactor Physics Br, RDT:RE

Special Technology $\mathrm{Br}, \mathrm{RDT}: \mathrm{RT}$

LMFBR Program Manager, RDT:PM

Asst Dir for Engrg Standards, RDT

Fuel Engineering $\mathrm{Br}, \mathrm{RDT}: \mathrm{RE}$

226 AEC Division of Technical Information Extension

1 AEC Idaho Operation Office

$$
\text { Nuclear Technology Division }
$$

C. W. Bills, Director

1 AEC San Francisco Operations Office Director, Reactor Division 
No. of

Copies

5

AEC Site Representatives

Argonne National Laboratory - $\mathrm{CH}$

Argonne National Laboratory - ID

Atomics International

General Electric Co.

Westinghouse Electric Corporation

3

Argonne National Laboratory

R. A. Jaross

LMFRB Program office

N. J. Swanson

1 Atomic Power Development Assoc.

Document Librarian

5

Atomics Internationa1:

FFTF Program Office

2 Babcock \& Wilcox Co.

Atomic Energy Division

S. H. Esleeck

G. B. Garton

1 Bechte1 Corporation

J. J. Teachnor

1 Combustion Engineering

$1000 \mathrm{MWe}$ Fol10w-On Study

W. P. Staker, Project Manager

1 Combustion Engineering

911 West Main Street

Chattanooga, Tennessee' 37401

Mrs. Nell Holder, Librarian

4 General Electric Company

Advanced Products Operation

Kar1 Coben

1 Genera1 Electric Compani

Nucleonics Laboratory

P. 0. Box 846

Pleasanton, California 94566

Dr. H. W. Alter 
No. of

Copies

2. Gulf General Atomic Inc.

General Atomic Division

D. Coburn

1 Idaho Nuclear Corporation

J. A. Buckham

1 Liquid Metal Engineering Center

R. W. Dickinson

2 Liquid Metal Information Center

A. E. Miller

2 Oak Ridge National Laboratory

W. O. Harms

1 Stanford University

Nuclear Division

Division of Mechanical Engrg

R. Sher

1 United Nuclear Corporation

Research and Engineering Center

R. F. DeAnge 1 is

10

Westinghouse Electric Corporation

Atomic Power Division

Advanced Reactor Systems

D. C. Spencer

\section{ONSITE-HANFORD}

1 AEC Chicago Patent Group

R. K. Sharp

2 AEC Richland Operations Office

J. M. Shivley

3 Battelle Memorial Institute

$7 \quad$ Battelle-Northwest

BNW - Technical Information (5)

BNW - Technical publication (2) 
No. of

Copies

1

Bechte1 Corporation

W. A. Smith (Richland)

3. RDT Assistant Director for

Pacific Northwest Laboratories

T. A. Nemzek

WADCO Corporation

G. L. Alkire

H. J. Anderson

S. O. Arneson

J. M. Atwood

R. W. Barker

J. M. Batch

J. F. Bates

R. K. Bierlein

L. D. Blackburn

H. R. Bragar

C. P. Cabell

J. R. Carrel1

T. T. Claudson

J. C. Cochran

G. S. Cochrane

W. H. Esselman

E. A. Evans

R. L. Fish

W. M. Gajewski

E. R. Gilbert

G. L. Guthrie

J. E. Hanson

K. M. Harmon

E. N: Heck

P. L. Hofmann

J. J. Hölmes

J. E. Irvin (2)

J. N. Judy
R. L. Knecht

J. J. Laidler

R. D. Leggett

F. J. Leitz

A. J. Love11 (15)

D. E. Mahagin

W. B. McDonald

J. S. McMahon

R. A. Moen

J. M. Norris

M. M. Paxton

R. E. Peterson

B. G. Rieck

W. E. Roake

G. J. Rogers

W. F. Sheely

F. R. Shober

J.L. Straalsund

C. D. Swanson

J. C. Tobin

K. G. Toyoda

L. D. Turner

A. L. Ward

B. Wolfe

W. R. Wykoff

WADCO Document Control (15)

WADCO Tech Pubs (703) 